\title{
REVISED A putative antiviral role of plant cytidine deaminases
}

\section{[version 2; peer review: 2 approved]}

\author{
Susana Martín1, José M. Cuevas (Di)1,2, Ana Grande-Pérez³,4, Santiago F. Elena1,2,5 \\ ${ }^{1}$ Instituto de Biología Molecular y Celular de Plantas (IBMCP), CSIC-Universidad Politécnica de València, Campus UPV CPI 8E, \\ Ingeniero Fausto Elio s/n, 46022 València, Spain \\ 2Instituto de Biología Integrativa de Sistemas (I2SysBio), CSIC-Universitat de València, Parc Científic UV, Catedrático Agustín \\ Escardino 9, 46980 Paterna, València, Spain \\ 3Área de Genética, Universidad de Málaga, Campus de Teatinos, 29071 Málaga, Spain \\ 4Instituto de Hortofruticultura Subtropical y Mediterránea “La Mayora”, CSIC-Universidad de Málaga, Campus de Teatinos, 29071 \\ Málaga, Spain \\ 5The Santa Fe Institute, 1399 Hyde Park Road, Santa Fe, NM, 87501, USA
}

\section{V2 First published: 03 May 2017, 6:622 \\ https://doi.org/10.12688/f1000research.11111.1}

Latest published: 15 Jun 2017, 6:622

https://doi.org/10.12688/f1000research.11111.2

\begin{abstract}
Background: A mechanism of innate antiviral immunity operating against viruses infecting mammalian cells has been described during the last decade. Host cytidine deaminases (e.g., APOBEC3 proteins) edit viral genomes, giving rise to hypermutated nonfunctional viruses; consequently, viral fitness is reduced through lethal mutagenesis. By contrast, sub-lethal hypermutagenesis may contribute to virus evolvability by increasing population diversity. To prevent genome editing, some viruses have evolved proteins that mediate APOBEC3 degradation. The model plant Arabidopsis thaliana genome encodes nine cytidine deaminases (AtCDAs), raising the question of whether deamination is an antiviral mechanism in plants as well. Methods: Here we tested the effects of expression of AtCDAs on the pararetrovirus Cauliflower mosaic virus (CaMV). Two different experiments were carried out. First, we transiently overexpressed each one of the nine A. thaliana AtCDA genes in Nicotiana bigelovii plants infected with CaMV, and characterized the resulting mutational spectra, comparing them with those generated under normal conditions. Secondly, we created $A$. thaliana transgenic plants expressing an artificial microRNA designed to knock-out the expression of up to six AtCDA genes. This and control plants were then infected with CaMV. Virus accumulation and mutational spectra where characterized in both types of plants.

Results: We have shown that the A. thaliana AtCDA1 gene product exerts a mutagenic activity, significantly increasing the number of $G$ to A mutations in vivo, with a concomitant reduction in the amount of CaMV genomes accumulated. Furthermore, the magnitude of this mutagenic effect on CaMV accumulation is positively correlated with the level of AtCDA1 mRNA expression in the plant.
\end{abstract}

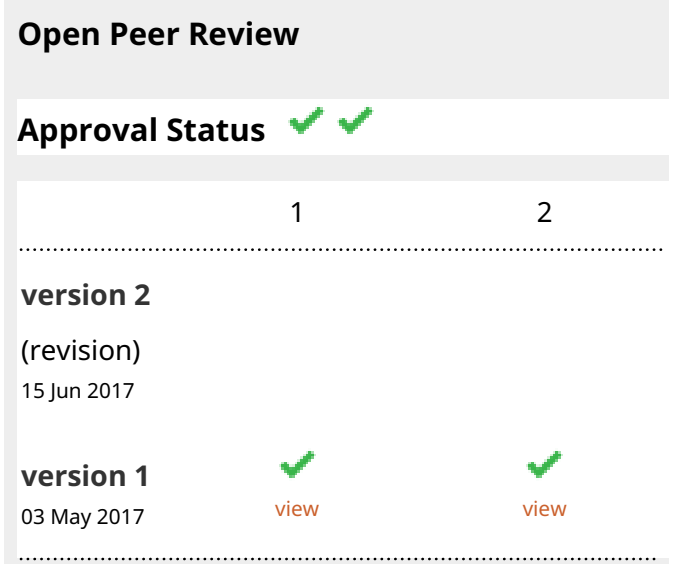

1. Pedro Gomez ID, CEBAS - CSIC (Centre for Applied Soil Science and Biology of the Segura) - (Spanish National Research Council), Murcia, Spain

2. Israel Pagán, Technical University of Madrid, Madrid, Spain

Any reports and responses or comments on the article can be found at the end of the article. 
Conclusions: Our results suggest that deamination of viral genomes may also work as an antiviral mechanism in plants.

\section{Keywords}

antiviral innate immunity, Cauliflower mosaic virus, error catastrophe, hypermutagenesis, mutational spectrum, plant-virus interaction, pararetrovirus, virus evolution

\section{Corresponding author: Santiago F. Elena (sfelena@ibmcp.upv.es)}

Author roles: Martín S: Data Curation, Formal Analysis, Investigation, Methodology, Project Administration, Validation, Writing Original Draft Preparation; Cuevas JM: Data Curation, Investigation, Methodology, Validation, Writing - Original Draft Preparation; Grande-Pérez A: Investigation, Methodology; Elena SF: Conceptualization, Formal Analysis, Funding Acquisition, Investigation, Supervision, Validation, Visualization, Writing - Original Draft Preparation, Writing - Review \& Editing

Competing interests: No competing interests were disclosed.

Grant information: This work was supported by the former spanish Ministerio de Ciencia e Innovación-FEDER grant BFU2009-06993 to SFE. JMC was supported by the CSIC JAE-doc program/Fondo Social Europeo. AG-P was supported by a grant for Scientific and Technical Activities and by grant P10-CVI-65651, both from Junta de Andalucía. The funders had no role in study design, data collection and analysis, decision to publish, or preparation of the manuscript.

Copyright: @ 2017 Martín S et al. This is an open access article distributed under the terms of the Creative Commons Attribution License, which permits unrestricted use, distribution, and reproduction in any medium, provided the original work is properly cited. Data associated with the article are available under the terms of the Creative Commons Zero "No rights reserved" data waiver (CCO 1.0 Public domain dedication).

How to cite this article: Martín S, Cuevas JM, Grande-Pérez A and Elena SF. A putative antiviral role of plant cytidine deaminases [version 2; peer review: 2 approved] F1000Research 2017, 6:622 https://doi.org/10.12688/f1000research.11111.2

First published: 03 May 2017, 6:622 https://doi.org/10.12688/f1000research.11111.1 


\section{REVISED Amendments from Version 1}

In response to Reviewer 1, we have (i) specified the number of half-leafs per plant that were agroinfiltrated with each of the nine AtCDAs, (ii) mention in the Discussion the possibility of whether a low threshold in the number of $\mathrm{G}$ to $\mathrm{A}$ transition would be enough as to trigger the antiviral mutagenic effect, (iii) added extra text to the Discussion commenting on the synonymous/nonsynonymous nature of the mutations observed during the agroinfiltration experiments with the AtCDA1. Supplementary Table $\mathrm{S} 1$ has been also modified accordingly.

In response to Reviewer 2, we have (i) added text in the Material \& Methods section to justify our choice of $N$. bigelovii for the agroinfiltration experiments, (ii) rewrite some passages to make clear that our results only suggest a potential antiviral role for AtCDA1, (iii) added a new paragraph to the Discussion on the potential antiviral role of CDAs in other viral systems.

In addition, we are now citing in the discussion a highly relevant reference by Chen et al. 2016 that was published very recently.

\section{See referee reports}

\section{Introduction}

The human APOBEC (apolipoprotein B mRNA editing catalytic polypeptide-like) family includes enzymes that catalyze the hydrolytic deamination of cytidine to uridine or deoxycytidine to deoxyuridine. This family is composed of eleven known members: APOBEC1, APOBEC2, APOBEC3 (further classified as A3A to $\mathrm{A} 3 \mathrm{H}$ ), APOBEC4, and AID (activation induced deaminase). APOBEC proteins are associated with several functions involving editing of DNA or RNA (reviewed by Smith et $a l^{1}$ ). APOBEC1 mediates deamination of cytidine at position 6666 of apolipoprotein $\mathrm{B}$ mRNA, resulting in the introduction of a premature stop codon and the production of the short form of the protein ${ }^{2-4}$. APOBEC2 is essential for muscle tissue development ${ }^{5}$. APOBEC4 has no ascribed function so far ${ }^{6}$. AID deaminates genomic ssDNA of B cells, initiating immunoglobulin somatic hypermutation and class switch processes ${ }^{7-9}$. Most notably, APOBEC3 enzymes participate in innate immunity against retroviruses and endogenous retroelements ${ }^{10-12}$. Sheehy et al. demonstrated that A3G also plays a role in immunity against human immunodeficiency virus type 1 (HIV-1) ${ }^{13}$. For its antiviral role, A3G is packaged along with viral $\mathrm{RNA}^{14}$. Upon infection of target cells and during the reverse transcription process, $\mathrm{A} 3 \mathrm{G}$ deaminates the cytosine residues of the nascent first retroviral DNA strand into uraciles. The resulting uracil residues serve as templates for the incorporation of adenine, which at the end result in strand-specific C/G to T/A transitions and loss of infectivity through lethal mutagenesis ${ }^{15-19}$. On the other hand, sub-lethal mutagenic activity of APOBEC3 proteins may end up being an additional source for HIV-1 genetic diversity, hence bolstering its evolvability ${ }^{20-22}$. APOBEC3 proteins have been shown to inhibit other retroviruses (simian immunodeficiency virus $^{23}$, equine infectious anemia virus ${ }^{24}$, foamy virus ${ }^{25}$, human T-cell leukemia virus ${ }^{26}$, and murine leukemia virus ${ }^{27}$ ), pararetroviruses (hepatitis B virus ${ }^{28}$ ) and DNA viruses (herpes simplex virus $1^{29,30}$, Epstein-Barr virus ${ }^{30}$, HSV-1 and EBV respectively, and human papillomavirus ${ }^{31}$ ). In the cases of HSV-1 and EBV, the antiviral role of deaminases has not yet been demonstrated ${ }^{30}$. Evidence also exists that A3G significantly interferes with negative-sense RNA viruses lacking a DNA replicative phase ${ }^{32}$. For example, the transcription and protein accumulation of measles virus, mumps virus and respiratory syncytial virus (RSV) was reduced 50-70\%, whereas the frequency of $\mathrm{C} / \mathrm{G}$ to U/A mutations was $~ 4$-fold increased after overexpressing A3G in Vero cells ${ }^{32}$. In contrast, A3G plays no antiviral activity against influenza A virus despite being highly induced in infected cells as part of a general IFN- $\beta$ response to infection ${ }^{33,34}$.

Human APOBEC belongs to a superfamily of polynucleotide cytidine and deoxycytidine deaminases distributed throughout the biological world $^{35}$. All family members contain a zinc finger domain (CDD), identifiable by the signature (H/C)-x-E-x25-30P-C-x-x-C. Plants are not an exception and, for example, the Arabidopsis thaliana genome encodes nine putative cytidine deaminases (with genes named AtCDA1 to AtCDA9). Whilst the AtCDA1 gene is located in chromosome II, the other eight genes are located in chromosome IV. In the case of rice and other monocots, only one CDA has been identified $^{35}$. Interestingly, this CDA expression was highly induced as part of the general stress response of rice against infection of the fungal pathogen Magnaporthe grisea, resulting in an excess of A to $\mathrm{G}$ and $\mathrm{U}$ to $\mathrm{C}$ mutations in defense-related genes ${ }^{36}$. Edited dsRNAs might be retained in the nucleus and degraded, generating miRNAs and siRNAs ${ }^{37}$. Given the relevance of deamination as an antiviral innate response in animals, we sought first to determine whether any of the AtCDA proteins encoded by plants can participate in deaminating the genome of the pararetrovirus, cauliflower mosaic virus (CaMV; genus Caulimovirus, family Caulimoviridae) and, second, we sought to explore whether this deamination may negatively impact viral infection. We hypothesize that deamination may take place mainly at the reverse transcription step. The CaMV genome is constituted by a single molecule of circular double-stranded DNA of $8 \mathrm{kbp}^{38}$. The DNA of CaMV has three discontinuities, $\Delta 1$ in the negative-sense strand (or $a$ strand), and $\Delta 2$ and $\Delta 3$ in the positivesense strand (yielding the $b$ and $g$ strands). In short, the replication cycle of CaMV is as follows ${ }^{38}$ : in the nucleus of the infected cell, the $a$ strand is transcribed into 35S RNA, with terminal repeats, that migrates to the cytoplasm. Priming of the 35S RNA occurs by the annealing of the 3' end of tRNA ${ }^{\text {met }}$ to the primer-binding site (PBS) sequence, leading to the synthesis of the DNA $a$ strand by the virus' reverse transcriptase. Then, the RNA in the heteroduplex is degraded by the virus' $\mathrm{RNaseH}$ activity, leaving purine-rich regions that act as primers for the synthesis of the positive-sense DNA $b$ and $g$ strands.

Our results show that $A t C D A 1$ significantly increases the number of $\mathrm{G}$ to $\mathrm{A}$ mutations in vivo, and that there is a negative correlation between the amount of AtCDAl mRNA present in the cell and the load reached by CaMV, suggesting that deamination of viral genomes may also constitute a significant antiviral mechanism in plants.

\section{Methods}

Transient overexpression of AtCDAs in Nicotiana bigelovii plants infected with CaMV

AtCDAs cDNAs were cloned under the $35 \mathrm{~S}$ promoter in a pBIN61 vector ${ }^{39}$. N. bigelovii plants were inoculated with CaMV virions purified from Brassica rapa plants $^{40}$ previously infected with the clone pCaMVW260 ${ }^{41}$. N. bigelovii was chosen for 
this particular experiment for practical reasons: it is susceptible to CaMV infection, while Nicotiana benthamiana is not, and it is easily agroinfiltrated. Three symptomatic leafs were agroinfiltrated ${ }^{39}$ with one of the nine $A t C D A$ s and with the empty vector pBIN61, each on one half of the leaf. Samples were collected three days post-agroinfiltration.

Inducible co-suppression of multiple AtCDAs by RNAi

The design and cloning of the artificial micro-RNA (amiR) able to simultaneously suppress the expression of $A t C D A s ~ 1,2,3,4,7$, and 8 was performed as described in ref. 42. The amiRNA was cloned under the control of Aspergillus nidulans ethanol regulon ${ }^{43,44}$ and used to transform A. thaliana by the floral dip method ${ }^{45}$. By doing so, we obtained the transgenic line amiR1-6-3. One-month-old seedlings of transgenic and wild-type A. thaliana were treated with $2 \%$ ethanol (or water for the control groups) three times every four days. Three days after the third treatment, plants were inoculated with the infectious clone pCaMVW260 as described in ref. 41. Infections were established by applying $1.31 \times 10^{11}$ molecules of pCaMVW260 to each of three leaves per plant. Subsequently, plants were subjected to two additional treatments with $2 \%$ ethanol (or water) one and five days post-infection. Finally, samples were taken eight days after inoculation and handled as previously described ${ }^{46}$. For each genotype (transgenic or wildtype) and treatment (ethanol or water) combination, 22 plants were analyzed.

\section{Detection of $\mathrm{A} / \mathrm{T}$ enriched genomes}

CaMV genomic DNA was purified using DNeasy Plant Mini Kit (Qiagen) according to manufacturer's instructions. For detection of edited genomes 3D-PCR was performed using primers HCa8Fdeg and HCa8Rdeg. PCRs were performed in a Mastercycler ${ }^{\circledR}$ (Eppendorf) at denaturation temperatures $82.1^{\circ} \mathrm{C}, 82.9^{\circ} \mathrm{C}, 83.9^{\circ} \mathrm{C}$, and $85.0^{\circ} \mathrm{C}$. The $229 \mathrm{nt}$ long PCR products obtained with the lowest denaturation temperature were cloned in pUC19 vector (Fermentas), transformed in Escherichia coli DH5 $\alpha$ and sent to GenoScreen (Lille, France) for sequencing.

\section{RT-qPCR analysis of AtCDA1 mRNA and qPCR analysis of CaMV load in transgenic plants}

Total RNA was extracted from A. thaliana plants using the RNeasy $^{\circledR}$ Plant Mini Kit (Qiagen), according to manufacturer's instructions. AtCDA1 specific primers qCDA1-F and qCDA1-R were designed using Primer Express software (Applied Biosystems). RT-qPCR reactions were performed using the One Step SYBR PrimeScript RT-PCR Kit II (Takara). Amplification, data acquisition and analysis were carried out using an Applied Biosystems Prism 7500 sequence detection system. All quantifications were performed using the standard curve method. To quantify AtCDA1 mRNA, a full-ORF runoff transcript was synthetized with T7 RNA polymerase (Roche) using as template a PCR product obtained from cloned AtCDA1 and primers T7-CDA1F and qCDA1-R. CaMV qPCR quantitation was performed as described in ref. 46.
Primers

All primers used are listed in Supplementary Table S3.

\section{Results}

Effect of AtCDAs overexpression on CaMV mutational spectrum

To test the mutagenic activity of $A$. thaliana CDAs, nine $N$. bigelovii plants were inoculated with CaMV. After systemic infection was established, we performed transient AtCDA overexpression experiments. To do so, the same leaf was agroinfiltrated twice; one half of the leaf was infiltrated with one of the nine AtCDA genes and the other half of the leaf was infiltrated with the empty vector. This test was done for all nine AtCDA genes in different plants. The presence of $A t C D A$ mRNAs was verified by RT-PCR from DNase-treated RNA extracts. DNA was extracted from agroinfiltrated areas for 3D-PCR amplification of a 229 bp fragment in the ORF VII of CaMV. 3D-PCR uses a gradient of low denaturation temperatures during PCR to identify the lowest one, which potentially allows differential amplification of $\mathrm{A} / \mathrm{T}$ rich hypermutated genomes ${ }^{47}$. There were no differences in the lowest denaturation temperature that could result in differential amplification of controls and the AtCDA-agroinfiltrated samples, suggesting that hypermutated genomes should be at low frequency, if present at all.

PCR products obtained at the lowest denaturation temperature were cloned and sequenced. In a preliminary experiment, we sequenced 25 clones from each AtCDA/negative control pair (Supplementary Table S1). At least one $\mathrm{G}$ to A transition was detected in clones from areas infiltrated with AtCDA1, AtCDA2 and AtCDA9 genes. For these three genes, we further increased the number of sequenced clones up to 106 . The CaMV mutant spectra was significantly different between plants overexpressing AtCDA1 and their respective negative controls (Figure 1a: $\chi^{2}=25.760,7$ d.f., $P=0.001$ ). This difference was entirely driven by the $471.43 \%$ increase in G to A transitions observed in the plants overexpressing AtCDA1. A thorough inspection of alignments showed that most of the $\mathrm{G}$ to $\mathrm{A}$ mutations $(65.6 \%)$ detected in the different samples were located at the nucleotide position 181 (Supplementary Table S1). By contrast, no overall difference existed between the mutant spectra of CaMV populations replicating in plants overexpressing AtCDA2 (Figure 1b: $\chi^{2}=8.944,6$ d.f., $P=0.177$ ) or AtCDA9 (Figure 1c: $\chi^{2}=6.539,8$ d.f., $\left.P=0.587\right)$ and their respective controls. Consistently, the mutant spectra from the three AtCDA-overexpressed samples were significantly heterogeneous $\left(\chi^{2}=41.063\right.$, 16 d.f., $P=0.001$ ), again due to the enrichment in $\mathrm{G}$ to A transitions observed in the case of AtCDA1. By contrast, the three independent control inoculation experiments showed homogeneous mutant spectra for CaMV ( $\chi^{2}=14.605,18$ d.f., $P=0.689$ ), undistinguishable from the mutant spectra previously reported for natural isolates of this virus ${ }^{48}$. The consistency of the mutant spectra observed for the three control experiments and with the spectrum described for a natural isolate of the virus suggests that under the physiological expression level of AtCDA1, the CaMV mutant spectrum is rather stable. 
(a)

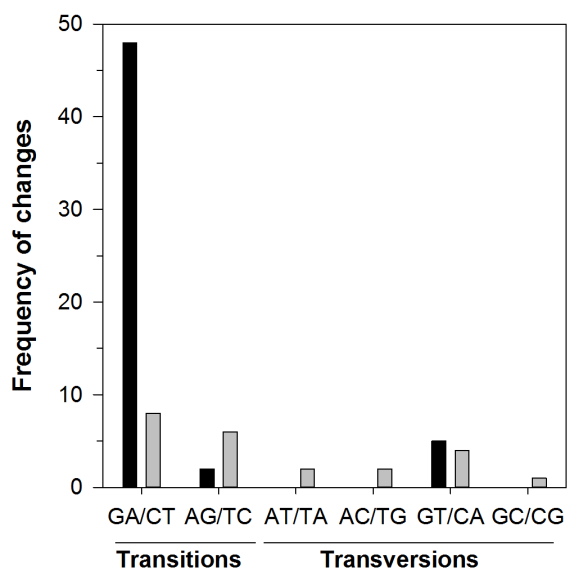

(b)

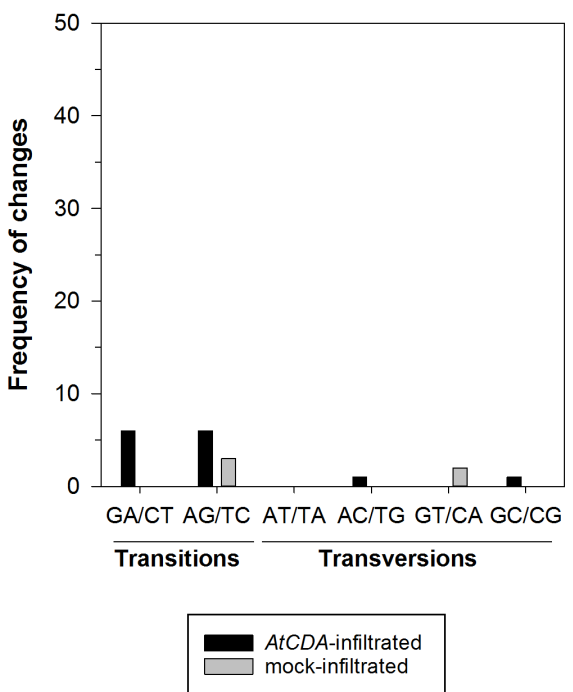

(c)

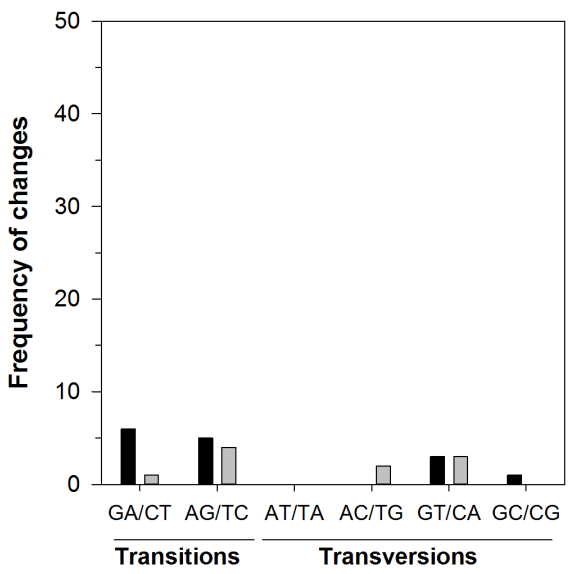

Figure 1. Number of mutations in CaMV genomes isolated from plant tissues agroinfiltrated with different AtCDAs. (a) AtCDA1, (b) AtCDA2 and (c) AtCDA9. The pBIN61 empty vector was agroinfiltrated in the same leaves than their corresponding AtCDAs (mock). For each sample 20,034 nucleotides were sequenced.

We conclude that overexpressing the AtCDAl gene results in a significant shift in CaMV genome composition towards $\mathrm{G}$ to $\mathrm{A}$ mutations, as expected from cytidine deaminase hypermutagenic activity.

\section{Effect of suppressing AtCDA expression on the viral load and mutational spectrum of CaMV}

To test the effects of suppressing the expression of $A t C D A$ on viral accumulation we produced a transgenic line of A. thaliana Col-0, named amiR1-6-3. This line was stably transformed with an amiR, controlled by the A. nidulans ethanol regulon to achieve ethanoltriggered RNAi-mediated simultaneous suppression of AtCDAs $1,2,3,4,7$, and 8 expression. Transgenic and wild-type plants were subjected to periodical treatment with $2 \%$ ethanol (or water for the control groups). Subsequently, plants were inoculated with the infectious clone pCaMVW260 that expresses the genome of CaMV. Samples were taken eight days after inoculation and AtCDA1 mRNA and CaMV viral load were quantified by real time RT-qPCR and qPCR, respectively, in the same samples. For each genotype and/or treatment, 22 plants were analyzed.

The expression of AtCDAl mRNA depended on the plant genotype (Figure 2a; GLM: $\chi^{2}=28.085,1$ d.f., $P<0.001$ ) as well as on the interaction of plant genotype and treatment $\left(\chi^{2}=26.037,1\right.$ d.f., $P<0.001$ ), suggesting a differential accumulation of AtCDA1 mRNA on each plant genotype depending on the amiR1-6-3 induction state. Ethanol treatment reduced the amount of AtCDA1 mRNA by $24.01 \%$ in transgenic plants, proving that triggering the expression of the amiR1-6-3 significantly and efficiently silences the expression of AtCDA1. Unexpectedly, the effect was the opposite in wild-type plants, for which we observed $23.76 \%$ increase in AtCDA1 mRNA accumulation (Figure 2a) upon treatment with ethanol. This increase in expression of AtCDA1 in wild-type plants after ethanol treatment and the underlying mechanisms certainly deserve to be investigated further. However, for the purpose of this study, its relevance is that it may increase the number of $\mathrm{G}$ to A mutations in the CaMV genome, thus making the antiviral effect stronger to some extent.

More interestingly, the relative accumulation of CaMV in ethanol-treated plants was significantly different, depending on the plant genotype being infected (Figure 2b; Mann-Whitney $U$ test, $P=0.002)$ : silencing the AtCDAl gene bolstered CaMV accumulation to $103.10 \%$ compared to the accumulation observed in wild-type plants. Furthermore, there was a significant negative correlation between the number of molecules of AtCDA1 mRNA and viral load (partial correlation coefficient controlling for treatment: $r=-0.299,86$ d.f., $P=0.005)$.

Given the significant increase of viral load in plants with lower levels of AtCDAl mRNA, we sought the molecular signature of deamination in transgenic plants. For this, we selected three biological replicates from each treatment group (ethanol or control) and sequenced between 39-45 clones of the CaMV fragment from each replicate. As shown in Figure 3, silencing of the AtCDAl gene affects the composition of CaMV mutant spectrum by reducing the number of $\mathrm{G}$ to A transitions by $69.23 \%$. Nevertheless, overall, both mutational spectra were not significantly different (Figure 3: $\chi^{2}=9.108,6$ d.f., $P=0.168$ ), prompting caution against making a definite conclusion on the role of deamination in the observed increase in CaMV accumulation.

We conclude that suppressing the expression of the AtCDAs 1, 2, $3,4,7$, and 8 significantly reduces the accumulation of CaMV. 
(a)

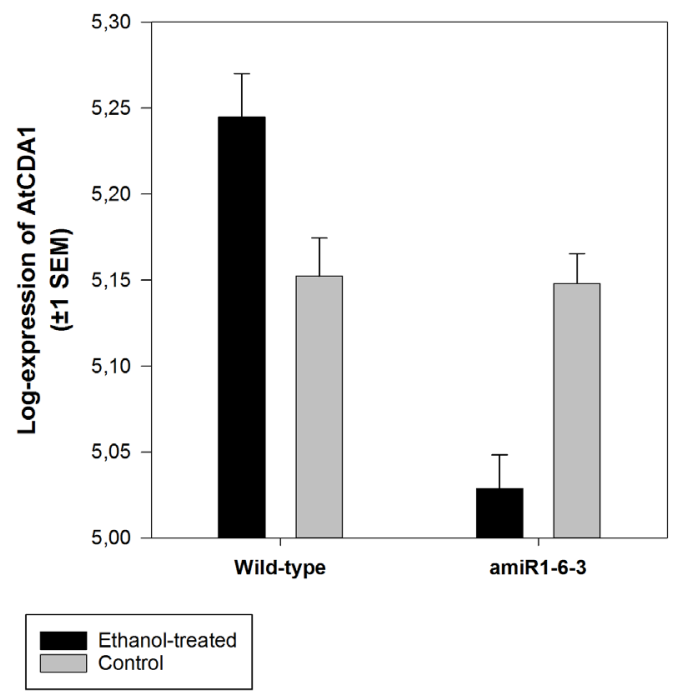

(b)

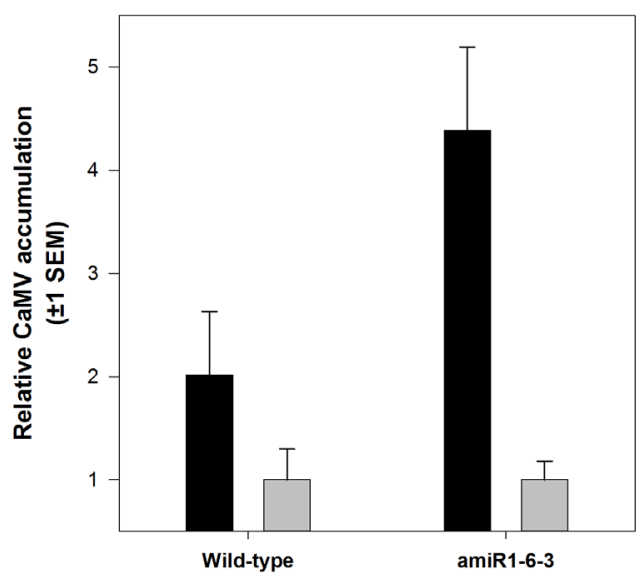

Figure 2. Accumulation of AtCDA1 mRNA molecules and CaMV genomes. (a) Number of AtCDA1 mRNA molecules/80 ng total RNA quantified by RT-qPCR using the standard curve method for absolute quantification. (b) Number of CaMV genomes/80 ng total DNA. For each block of plants (wild-type and amiR1-6-3), values were normalized to the average number of genomes estimated in the corresponding water-treated (control) plants.

However, the characterization of the mutant spectrum of the same CaMV populations provides no strong enough support to the cytidine deamination hypothesis.

\section{Discussion}

Lethal mutagenesis through deamination of RNA/DNA by cytidine deaminases has been proven to work as an antiviral mechanism against retroviruses ${ }^{16-19,23-27}$, and some DNA ${ }^{28-31}$ and $\mathrm{RNA}^{32}$ viruses infecting mammals. Our results show that the $A$. thaliana $C D A 1$ gene has some degree of mutagenic activity on the pararetrovirus CaMV genome. Moreover, simultaneously suppressing the expression of a subset of $A t C D A$ s, including $A t C D A 1$, increased CaMV load, strongly suggesting an antiviral role for AtCDAs. This role of AtCDA1 is congruent with the very recent observation by Chen et al. that only the product of AtCDAl is required for in vivo homeostasis of pyrimidines while the other eight members of the gene family may be pseudogenes ${ }^{49}$

Our data show that AtCDAs probably restrict CaMV replication through a process similar to the restriction of HIV-1 by APOBEC3. CaMV replicates in the cytoplasm by reverse transcription using the positive-sense 35S RNA as template. As for HIV-1, the first strand negative-sense cDNA could be deaminated during reverse transcription, transforming deoxycytidine into deoxyuridine. Then, when the positive-sense strand is produced, an A is incorporated instead of a $\mathrm{G}$, increasing the proportion of $\mathrm{G}$ to $\mathrm{A}$ mutations. In the case of $\mathrm{HIV}-1$, this $\mathrm{G}$ to $\mathrm{A}$ mutational bias is explained by $\mathrm{A} 3 \mathrm{G}$ and $\mathrm{A} 3 \mathrm{H}$ specificity for single negative stranded DNA: during HIV-1 replication, $\mathrm{C}$ to $\mathrm{G}$ transitions are rare and restricted to the PBS site and $\mathrm{U} 3$ regions in the 5 ' long terminal repeat, where positive-stranded DNA is predicted to become transiently single stranded ${ }^{50}$. Similarly, during CaMV replication the negative strand remains single stranded, while the positive is copied from it and remains double stranded ${ }^{51}$. Surprisingly, for AtCDA1, C to T mutations were also increased; the region studied here is close to the 5 ' end of $\mathrm{CaMV}$, which contains the PBS for negative-strand synthesis and the ssDNA discontinuity $\Delta 1$. The observed $\mathrm{C}$ to $\mathrm{T}$ transitions could reflect transient positivestranded ssDNA in the 5' terminal region during reverse transcription, nevertheless a different substrate specificity of A. thaliana CDAs cannot be ruled out.

Evidences from studies with different mammalian viruses suggest that APOBEC enzymes may have an antiviral role not only against DNA viruses and retroviruses but also against some RNA viruses $^{32}$. Our evidences for a potential antiviral role of a plant CDA is restricted to the case of a pararetrovirus and thus the question is whether this mechanism would also operate against other types of plant viruses. Lin et al. described the spectrum of mutations accumulated in a non-coding sequence artificially inserted in the genome of turnip mosaic virus (TuMV), a prototypical RNA plant virus, during infection of $N$. benthamiana plants ${ }^{52}$. C to A and C to $U$ transitions were significantly over represented in the mutant spectrum, and the authors already suggested this bias was compatible with TuMV genome being edited by CDA enzymes ${ }^{52}$.

Most of the $\mathrm{G}$ to A transitions detected in agroinfiltration experiments were located in the $\mathrm{G}$ at position 181 . HIV-1 hypermutated genomes show mutational hot spots as well, which are due to preference of $\mathrm{A} 3 \mathrm{G}$ and $\mathrm{A} 3 \mathrm{~F}$ for deamination of the third $\mathrm{C}$ in 5'-CCC (negative-strand) and 5'-GGC, respectively ${ }^{53,54}$. The sequence context of the C complementary to G181 (5'-GGC) differs from what has been described for APOBEC3 as hotspot for deamination, suggesting that if AtCDAs had a context preference, it would be different from the one described for A3G. However, given the low number of mutations found, we should be cautious when concluding whether AtCDAs have a possible sequence-context preference. Since our experiments were performed in vivo, negative selection is expected to purge genomes carrying deleterious mutations. To explore this possibility, we have 


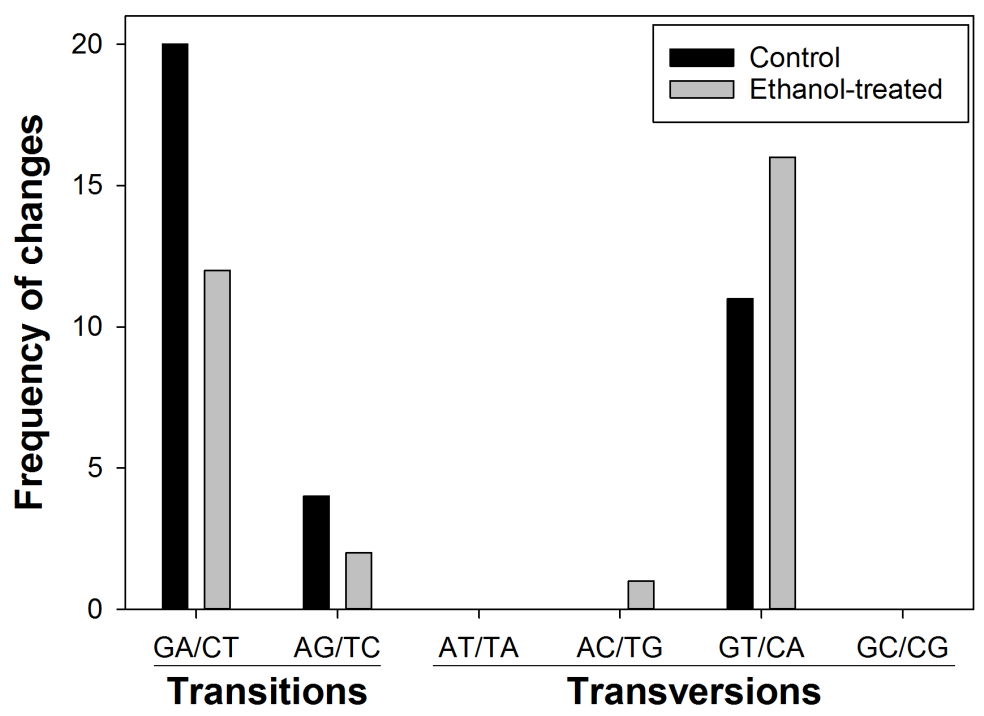

Figure 3. Number of mutations found pooling the CaMV sequences from ethanol-treated and control amiR1-6-3 plants (3 replicates). The number of nucleotides sequenced was 23,436 for control and 24,003 for ethanol-treated plants. Ethanol-treated plants turn on the expression of amiR1-6-3 that was designed to silence the expression of the AtCDA1 gene.

checked the consequence of mutations in the protein encoded by the ORF VII (Supplementary Table S1) for the case of plant agroinfiltrated with AtCDAl and its corresponding paired control. Eight out of the 22 different mutations observed in CaMV populations replicating in presence of AtCDA1 were nonsynonymous, thus in agreement with previous observations that most $\mathrm{G}$ to $\mathrm{A}$ transitions in CaMV are synonymous ${ }^{54}$. Two remarks can be made about these numbers. First, quite surprisingly, six of these eight nonsynonymous mutations resulted in stop codons affecting two different positions (amino acids C58 and Y71). Second, transition G181A is synonymous. For CaMV replicating in the corresponding control half-leaf (agroinfiltrated with the empty pBIN61 vector), three out of the 14 different mutations observed were nonsynonymous, one of them also resulting in an stop in codon 58. No significant differences exist among the relative ratio of nonsynonymous to synonymous mutations in both samples (Fisher's exact test $P=0.467)$. Despite the mutagenic effect of $A t \mathrm{CDA} 1$ over the CaMV population, the number of nonsynonymous mutations relative to the number of synonymous mutations is not altered, thus suggesting negative selection works, at least, as efficiently as it does in the control population. The same conclusion is reached if we only focus the comparison in the number of nonsynonymous mutations resulting in stop codons. This potential purifying effect of selection could account for our failure to detect largely hypermutated genomes, and demonstrates the need for developing new selection-free assays to further characterize AtCDA-induced mutagenesis. Despite the apparent low number of deamination mutations observed, it has a significant impact in CaMV accumulation (Figure $2 b$ ), thus suggesting that a low threshold of $\mathrm{G}$ to A transition bias may be enough to lead to a reduction in viral load.
Although there is not a demonstrated correlation between the expression of APOBEC3 and mutational bias of viruses infecting mammals, caulimoviruses have an excess of $\mathrm{G}$ to $\mathrm{A}$ transitions in synonymous positions ${ }^{55}$. In $A$. thaliana plants, we found that silencing of AtCDAl reduced the frequency of $\mathrm{G}$ to A transitions in the CaMV genome, suggesting a contribution of $A t C D A s$ to the nucleotide bias found in caulimoviruses. The increased viral load in CDA-silenced A. thaliana plants strongly suggests that deamination of viral genomes may work as an antiviral mechanism in plants, leading to questions about how general this mechanism might be, and how it may contribute to viral evolution. Describing a new natural antiviral mechanism in plants opens new research avenues for the development of new durable control strategies.

\section{Data availability}

All datasets that support the findings in this study are available at LabArchives with DOI: 10.6070/H4TD9VD5.

'File Sequence_data_for_Figure_1.zip' contains the FASTA files with the sequence data used to generate the mutational spectra shown in Figure 1.

'Data_for_Figure_2a.xlsx' contains the AtCDA1 expression data used to generate Figure 2a.

'Data_for_Figure_2b.xlsx' contains the CaMV accumulation data used to generate Figure $2 b$.

'Sequence_data_for_Figure_3.zip' contains the FASTA files with sequence data used to generate the mutational spectra shown in Figure 3. 


\section{Author contributions}

SFE conceived the study, designed the experiments and analyzed the data. SM, JMC and AG-P performed the experiments and contributed to experimental design. SM, JMC and SFE wrote the paper. All authors revised and approved the manuscript.

\section{Competing interests}

No competing interests were disclosed.

\section{Grant information}

This work was supported by the former Spanish Ministerio de Ciencia e Innovación-FEDER grant BFU2009-06993 to SFE. JMC was supported by the CSIC JAE-doc program/Fondo Social
Europeo. AG-P was supported by a grant for Scientific and Technical Activities and by grant P10-CVI-65651, both from Junta de Andalucía.

The funders had no role in study design, data collection and analysis, decision to publish, or preparation of the manuscript.

\section{Acknowledgements}

We thank Francisca de la Iglesia (IBMCP-CSIC), Àngels Pròsper (IBMCP-CSIC) and Ana Cuadrado (IBMCP-CSIC) for excellent technical assistance, Miguel A. Blázquez (IBMCP-CSIC) for help in designing the amiR1-6-3 and generating the transgenic plants and Rémy Froissart (BGPI-CNRS) for providing the pCaMVW260 infectious clone and the B. rapa and N. bigelovii seeds.

\section{Supplementary material}

Supplementary Table S1. Nucleotide substitutions detected in the overexpression experiments. For each of the nine infiltrated plants, the substitutions observed in the clonal sequences analyzed at the overexpressed (AtCDAl to AtCDA9) and control (pBIN61-infiltrated) regions are shown. In some cases, a given substitution is present in several clonal sequences from the same sample and the number of times it appears is indicated between parentheses. G to A transitions are shaded in grey. Nucleotide positions are given according to CaMV isolate W260, GenBank accession JF809616.1.

Click here to access the data.

Supplementary Table S2. Nucleotide substitutions found in A. thaliana transgenic plants with or without inducing the expression of amiR3-1-9 that silences the expression of several AtCDAs. In some cases, a given substitution is present in several clonal sequences from the same sample and the number of times it appears is indicated between brackets. G to A transitions are shaded in grey. Nucleotide positions are given according to CaMV isolate W260, GenBank accession JF809616.1.

Click here to access the data.

\section{Supplementary Table S3. Primers used in this study.}

Click here to access the data.

1. Smith HC, Bennett RP, Kizilyer A, et al.: Functions and regulation of the APOBEC family of proteins. Semin Cell Dev Biol. 2012; 23(3): 258-268. PubMed Abstract | Publisher Full Text | Free Full Text

2. Driscoll DM, Zhang Q: Expression and characterization of p27, the catalytic subunit of the apolipoprotein B mRNA editing enzyme. J Biol Chem. 1994; 269(31): 19843-19847. PubMed Abstract

3. Navaratnam N, Morrison JR, Bhattacharya S, et al.: The p27 catalytic subunit of the apolipoprotein B mRNA editing enzyme is a cytidine deaminase. $J$ Biol Chem. 1993; 268(28): 20709-20712. PubMed Abstract

4. Teng B, Burant CF, Davidson NO: Molecular cloning of an apolipoprotein B messenger RNA editing protein. Science. 1993; 260(5115): 1816-1819. PubMed Abstract | Publisher Full Text

5. Sato Y, Probst HC, Tatsumi R, et al.: Deficiency in APOBEC2 leads to a shift in muscle fiber type, diminished body mass, and myopathy. J Biol Chem. 2010; 285(10): 7111-7118.

PubMed Abstract | Publisher Full Text | Free Full Text

6. Rogozin IB, Basu MK, Jordan IK, et al: APOBEC4, a new member of the
AID/APOBEC family of polynucleotide (deoxy)cytidine deaminases predicted by computational analysis. Cell Cycle. 2005; 4(9): 1281-1285.

PubMed Abstract | Publisher Full Text

7. Muramatsu M, Sankaranand VS, Anant S, et al:: Specific expression of activation-induced cytidine deaminase (AID), a novel member of the RNAediting deaminase family in germinal center B cells. J Biol Chem. 1999; 274(26): editing deamina-18476.

18470-18476.
PubMed Abstract | Publisher Full Text

8. Arakawa $\mathrm{H}$, Hauschild J, Buerstedde JM: Requirement of the activation-induced deaminase (AID) gene for immunoglobulin gene conversion. Science. 2002; 295(5558): 1301-1306.

PubMed Abstract | Publisher Full Text

9. Fugmann SD, Schatz DG: Immunology. One AID to unite them all. Science. 2002 295(5558): 1244-1245.

PubMed Abstract | Publisher Full Text

10. Chiu YL, Witkowska HE, Hall SC, et al:: High-molecular-mass APOBEC3G complexes restrict Alu retrotransposition. Proc Natl Acad Sci U S A. 2006; 103(42): 15588-15593.

PubMed Abstract | Publisher Full Text | Free Full Text 
11. Schumann GG: APOBEC3 proteins: major players in intracellular defence against LINE-1-mediated retrotransposition. Biochem Soc Trans. 2007; 35(Pt 3): 637-642.

PubMed Abstract | Publisher Full Text

12. Esnault $\mathrm{C}$, Millet $\mathrm{J}$, Schwartz $\mathrm{O}$, et al.: Dual inhibitory effects of APOBEC family proteins on retrotransposition of mammalian endogenous retroviruses. NuCl Acids Res. 2006; 34(5): 1522-1531.

PubMed Abstract | Publisher Full Text | Free Full Text

13. Sheehy AM, Gaddis NC, Choi JD, et al:: Isolation of a human gene that inhibits HIV-1 infection and is suppressed by the viral Vif protein. Nature. 2002; 418(6898): 646-650.

PubMed Abstract | Publisher Full Text

14. Smith HC: АPOBEC3G: a double agent in defense. Trends Biochem Sci. 2011; 36(5): 239-244.

PubMed Abstract | Publisher Full Text | Free Full Text

15. Mangeat $B$, Turelli $P$, Caron $G$, et al:: Broad antiretroviral defence by human APOBEC $3 G$ through lethal editing of nascent reverse transcripts. Nature. 2003 ; 424(6944): 99-103.

PubMed Abstract | Publisher Full Text

16. Zhang $\mathrm{H}$, Yang B, Pomerantz RJ, et al:: The cytidine deaminase CEM15 induces hypermutation in newly synthesized HIV-1 DNA. Nature. 2003; 424(6944): 94-98.

PubMed Abstract | Publisher Full Text | Free Full Text

17. Browne EP, Allers C, Landau NR: Restriction of HIV-1 by APOBEC3G is cytidine deaminase-dependent. Virology. 2009; 387(2): 313-321. PubMed Abstract | Publisher Full Text | Free Full Text

18. Miyagi E, Opi S, Takeuchi $\mathrm{H}$, et al.: Enzymatically active APOBEC3G is required for efficient inhibition of human immunodeficiency virus type 1. J Virol. 2007; 81(24): 13346-13353.

PubMed Abstract | Publisher Full Text | Free Full Text

19. Schumacher AJ, Haché G, Macduff DA, et al:: The DNA deaminase activity of human APOBEC3G is required for Ty1, MusD, and human immunodeficiency virus type 1 restriction. J Virol. 2008; 82(6): 2652-2660. PubMed Abstract | Publisher Full Text | Free Full Text

20. Sadler HA, Stenglein MD, Harris RS, et al:: APOBEC3G contributes to HIV-1 variation through sublethal mutagenesis. $J$ Virol. 2010; 84(14): 7396-7404. PubMed Abstract | Publisher Full Text | Free Full Text

21. Mulder LC, Harari A, Simon V: Cytidine deamination induced HIV-1 drug resistance. Proc Natl Acad Sci U S A. 2008; 105(14): 5501-5506. PubMed Abstract | Publisher Full Text | Free Full Text

22. Russell RA, Moore MD, Hu WS, et al:: APOBEC3G induces a hypermutation gradient: purifying selection at multiple steps during HIV-1 replication results in levels of G-to-A mutations that are high in DNA, intermediate in cellular viral RNA, and low in virion RNA. Retrovirology. 2009; 6: 16 PubMed Abstract | Publisher Full Text | Free Full Text

23. Hultquist JF Lengyel JA, Refsland EW, et al: Human and rhesus APOBEC3D, APOBEC $3 F, A P O B E C 3 G$, and $A P O B E C 3 H$ demonstrate a conserved capacity to restrict Vif-deficient HIV-1. J Virol. 2011; 85(21): 11220-11234. PubMed Abstract | Publisher Full Text | Free Full Text

24. Zielonka J, Bravo IG, Marino D, et al.: Restriction of equine infectious anemia virus by equine APOBEC3 cytidine deaminases. J Virol. 2009; 83(15): $7547-7559$.

PubMed Abstract | Publisher Full Text | Free Full Text

25. Delebecque F, Suspène $R$, Calattini $S$, et al.: Restriction of foamy viruses by APOBEC cytidine deaminases. J Virol. 2006; 80(2): 605-614. PubMed Abstract | Publisher Full Text | Free Full Text

26. Mahieux R, Suspène $R$, Delebecque $F$, et al.: Extensive editing of a small fraction of Human T-cell leukemia virus type 1 genomes by four APOBEC 3 cytidine deaminases. J Gen Virol. 2005; 86(Pt 9): 2489-2494.

PubMed Abstract | Publisher Full Tex

27. Dang $Y$, Wang X, Esselman WJ, et al.: Identification of APOBEC3DE as another antiretroviral factor from the human APOBEC family. J Virol. 2006; 80(21): 10522-10533.

PubMed Abstract | Publisher Full Text | Free Full Text

28. Bonvin M, Achermann F, Greeve I, et al:: Interferon-inducible expression of APOBEC3 editing enzymes in human hepatocytes and inhibition of hepatitis $B$ virus replication. Hepatology. 2006; 43(6): 1364-1374. PubMed Abstract | Publisher Full Text

29. Gee $\mathrm{P}$, Ando $\mathrm{Y}$, Kitayama $\mathrm{H}$, et al.: APOBEC1-mediated editing and attenuation of Herpes simplex virus 1 DNA indicate that neurons have an antiviral role during herpes simplex encephalitis. J Virol. 2011; 85(19): 9726-9736. PubMed Abstract | Publisher Full Text | Free Full Text

30. Suspène R, Aynaud MM, Koch $\mathrm{S}$, et al:: Genetic editing of herpes simplex virus 1 and Epstein-Barr herpesvirus genomes by human APOBEC3 cytidine deaminases in culture and in vivo. J Virol. 2011; 85(15): 7594-7602. PubMed Abstract | Publisher Full Text | Free Full Text

31. Wang Z, Wakae K, Kitamura K, et al.: APOBEC3 deaminases induce hypermutation in human papillomavirus 16 DNA upon beta interferon stimulation. J Virol. 2014; 88(2): 1308-1317. PubMed Abstract | Publisher Full Text | Free Full Text

32. Fehrholz M, Kendl S, Prifert C, et al.: The innate antiviral factor APOBEC3G targets replication of measles, mumps and respiratory syncytial viruses. $J$ Gen Virol. 2012; 93(Pt 3): 565-576.

PubMed Abstract | Publisher Full Text
33. Pauli EK, Schmolke M, Hofmann $\mathrm{H}$, et al:: High level expression of the antiretroviral protein $A P O B E C 3 G$ is induced by influenza $A$ virus but does not confer antiviral activity. Retrovirology. 2009; 6: 38.

PubMed Abstract | Publisher Full Text | Free Full Text

34. Wang GF, Lin SY, Zhang $\mathrm{H}$, et al:: Apobec $3 \mathrm{~F}$ and apobec $3 \mathrm{G}$ have no inhibition and hypermutation effect on the human influenza A virus. Acta Virol. 2008 52(3): 193-194. PubMed Abstract

35. Conticello SG, Thomas CJ, Petersen-Mahrt SK, et al.: Evolution of the AID/APOBEC family of polynucleotide (deoxy)cytidine deaminases. Mol Biol Evol. 2005; 22(2): 367-377.

PubMed Abstract | Publisher Full Text

36. Gowda M, Venu RC, Li H, et al:: Magnaporthe grisea infection triggers RNA variation and antisense transcript expression in rice. Plant Physiol. 2007; 144(1): 524-533.

PubMed Abstract | Publisher Full Text | Free Full Text

37. Blow MJ, Grocock RJ, van Dongen S, et al: RNA editing of human microRNAs. Genome Biol. 2006; 7(4): R27.

PubMed Abstract | Publisher Full Text | Free Full Text

38. Haas M, Bureau M, Geldreich A, et al:: Cauliflower mosaic virus: still in the news. Mol Plant Pathol. 2002; 3(6): 419-429.

PubMed Abstract | Publisher Full Text

39. Bendahmane A, Querci M, Kanyuka K, et al:: Agrobacterium transient expression system as a tool for the isolation of disease resistance genes: application to the Rx2 locus in potato. Plant J. 2000; 21(1): 73-81.

PubMed Abstract | Publisher Full Text

40. Schoelz JE, Shepherd RJ, Daubert S: Region VI of cauliflower mosaic virus encodes a host range determinant. Mol Cell Biol. 1986; 6(7): 2632-2637. PubMed Abstract | Publisher Full Text | Free Full Text

41. Scholelz JE, Shepherd RJ: Host range control of cauliflower mosaic virus. Virology. 1988; 162(1): 30-37. PubMed Abstract | Publisher Full Text

42. Schwab R, Ossowski S, Riester M, et al.: Highly specific gene silencing by artificial microRNAs in Arabidopsis. Plant Cell. 2006; 18(5): 1121-1133. PubMed Abstract | Publisher Full Text | Free Full Text

43. Caddick MX, Greenland AJ, Jepson I, et al:: An ethanol inducible gene switch for plants used to manipulate carbon metabolism. Nat Biotech. 1998; 16(2): 177-180.

PubMed Abstract | Publisher Full Text

44. Roslan HA, Salter MG, Wood CD, et al.: Characterization of the ethanolinducible alc gene-expression system in Arabidopsis thaliana. Plant J. 2001; 28(2): 225-235.

PubMed Abstract | Publisher Full Text

45. Clough SJ, Bent AF: Floral dip: a simplified method for Agrobacteriummediated transformation of Arabidopsis thaliana. Plant J. 1998; 16(6): 735-743. PubMed Abstract | Publisher Full Text

46. Martín S, Elena SF: Application of game theory to the interaction between plant viruses during mixed infections. J Gen Virol. 2009; 90(Pt 11): 2815-2820. PubMed Abstract | Publisher Full Tex

47. Suspène R, Henry M, Guillot $S$, et al:: Recovery of APOBEC3-edited human immunodeficiency virus $\mathrm{G}->\mathrm{A}$ hypermutants by differential DNA denaturation PCR. J Gen Virol. 2005; 86(Pt 1): 125-129.

PubMed Abstract | Publisher Full Text

48. Chenault KD, Melcher U: Patterns of nucleotide sequence variation among cauliflower mosaic virus isolates. Biochimie. 1994; 76(1): 3-8. PubMed Abstract | Publisher Full Text

49. Chen M, Herde M, Witte CP: Of the Nine Cytidine Deaminase-Like Genes in Arabidopsis, Eight Are Pseudogenes and Only One Is Required to Maintain Pyrimidine Homeostasis in Vivo. Plant Physiol. 2016; 171(2): 799-809. PubMed Abstract | Publisher Full Text | Free Full Text

50. Yu Q, König R, Pillai S, et al:: Single-strand specificity of APOBEC3G accounts for minus-strand deamination of the HIV genome. Nat Struct Mol Biol. 2004; 11(5): 435-42.

PubMed Abstract | Publisher Full Text

51. Marco $\mathrm{Y}$, Howell SH: Intracellular forms of viral DNA consistent with a model of reverse transcriptional replication of the cauliflower mosaic virus genome. Nucl Acids Res. 1984; 12(3): 1517-1528.

PubMed Abstract | Publisher Full Text | Free Full Text

52. Lin SS, Wu HW, Elena SF, et al.: Molecular evolution of a viral non-coding sequence under the selective pressure of amiRNA-mediated silencing. PLOS Pathog. 2009; 5(2): e1000312. PubMed Abstract | Publisher Full Text | Free Full Text

53. Liddament MT, Brown WL, Schumacher AJ, et al:: APOBEC3F properties and hypermutation preferences indicate activity against HIV-1 in vivo. Curr Biol. 2004; 14(15): 1385-91.

PubMed Abstract | Publisher Full Text

54. Kohli RM, Maul RW, Guminski AF, et al.: Local sequence targeting in the AID/APOBEC family differentially impacts retroviral restriction and antibody diversification. J Biol Chem. 2010; 282(52): 40956-40964.

PubMed Abstract | Publisher Full Text | Free Full Text

55. Müller V, Bonhoeffer S: Guanine-adenine bias: a general property of retroid viruses that is unrelated to host-induced hypermutation. Trends Genet. 2005; 21(5): 264-268.

PubMed Abstract | Publisher Full Text 


\section{Open Peer Review}

\section{Current Peer Review Status:}

\section{Version 1}

Reviewer Report 02 June 2017

https://doi.org/10.5256/f1000research.11987.r22486

(C) 2017 Pagán I. This is an open access peer review report distributed under the terms of the Creative Commons Attribution License, which permits unrestricted use, distribution, and reproduction in any medium, provided the original work is properly cited.

\section{Israel Pagán}

Center for Biotechnology and Plant Genomics (CBGP); E.T.S.I. Agrónomos ( Higher Technical School of Agricultural Engineering), Technical University of Madrid, Madrid, Spain

Martín et al. present an interesting work on the role of plant cytidine deaminases (CDA) as a defense mechanism against virus infection through the increase of mutational load in the viral genome during replication. CDAs are known to increase the frequency of $\mathrm{G}$ to $\mathrm{A}$ transitions. Although such mutational load has been shown to be a effective defense mechanism against some animal viruses (mainly retroviruses), this paper shows for the first time evidence that support a similar role in plants against a plant pararetrovirus. As such, I consider the paper scientifically sound.

I find the paper well written and easy to read, and I would like to acknowledge the effort made by the authors on this aspect. The methodology is well described and all the information necessary to understand the experiments is provided. On this sense, I would just suggest adding complementary information on the number of leaves from the $N$. bigelovii agroinfiltrated with each AtCDA. This would help to understand the degree of biological variation considered in the study.

The main conclusion of the manuscript is that overexpression of AtCDA leads to a decrease of viral load. I think that this conclusion is robustly supported by the data presented in the result section, and statistics are flawlessly performed and described as is the rule in the work from Prof. Elena's group. A second main conclusion of this work is that higher viral load may be associated with the trend towards reduced frequency of $G$ to $A$ transitions in plants with silenced AtCDA. The authors are careful on drawing conclusions from this observation, given that the observed trend is not statistically significant. I was wondering whether the effect of the bias in $\mathrm{G}$ to $\mathrm{A}$ transitions might not be quantitative but rather qualitative. In other words, it might be interesting some discussion about the existence of a threshold in the frequency of $\mathrm{G}$ to $\mathrm{A}$ transitions bias that may lead to the reduction in viral load.

My last suggestion relates to the observation that mutations at position 181 accounts for most of the $\mathrm{G}$ to $\mathrm{A}$ transitions. This makes me wonder about the spatial distribution of mutations 
(especially $\mathrm{G}$ to $\mathrm{A}$ transitions) across the viral genome. I think that including some information on whether mutations are mainly localized in coding or non-coding regions, and on whether mutations located in coding regions results mainly in synonymous and non-synonymous changes may be a nice addition. Perhaps this information may help to understand the effects of $G$ to $A$ transitions in the genome "functionality".

Is the work clearly and accurately presented and does it cite the current literature? Yes

Is the study design appropriate and is the work technically sound? Yes

Are sufficient details of methods and analysis provided to allow replication by others? Yes

If applicable, is the statistical analysis and its interpretation appropriate? Yes

Are all the source data underlying the results available to ensure full reproducibility? Yes

Are the conclusions drawn adequately supported by the results? Yes

Competing Interests: No competing interests were disclosed.

Reviewer Expertise: Plant virus evolution

I confirm that I have read this submission and believe that I have an appropriate level of expertise to confirm that it is of an acceptable scientific standard.

Author Response ( ) 09 Jun 2017

Santiago F Elena, Evolutionary Systems Virology Group, Instituto de Biología Integrativa de Sistemas (CSIC-UV), Spain

Dear Dr. Pagán,

Thank you very much for your time in reviewing the manuscript and also for your very constructive comments. Below we provide detailed responses to each one of them.

1. We now mention the number of half-leafs per plant (3) that were agroinfiltrated with each one of the nine AtCDAs.

2. We have added a brief text to the Discussion on the possibility of whether low a threshold number of $\mathrm{G}$ to $\mathrm{A}$ transitions needs to be reached in order to have a significant effect on CaMV accumulation.

3. Please, recall that we have sequenced only a region within ORF VII, thus all mutations observed are in a coding sequence. Nonetheless, we have added extra text to the 
Discussion commenting on the synonymous/nonsynonymous nature of all the observed mutations, in particular for the $G$ to A transitions most relevant for our study. Furthermore, Supplementary Table S1 now indicates the nonsynonymous substitutions for the case of AtCDA1 in the agroinfiltration experiments.

Competing Interests: No competing interests were disclosed.

Reviewer Report 18 May 2017

https://doi.org/10.5256/f1000research.11987.r22521

(c) 2017 Gomez P. This is an open access peer review report distributed under the terms of the Creative Commons Attribution License, which permits unrestricted use, distribution, and reproduction in any medium, provided the original work is properly cited.

\section{Pedro Gomez}

Department of Stress Biology and Plant Pathology, CEBAS - CSIC (Centre for Applied Soil Science and Biology of the Segura) - (Spanish National Research Council), Murcia, Spain

Comments of the manuscript entitled "A putative antiviral role of plant cytidine deaminases".

This manuscript reports how plant cytidine deaminases, particularly AtCDA1, might contribute to the deamination of Cauliflower mosaic virus (CaMV) genome, and hence, affect its viral accumulation in plants. The work has merit and seems to be a good contribution. Whereas this potential antiviral response has been assessed in human and animals, virtually nothing is known about this mutagenic activity in plants.

The experimental methods are overall solid, and the manuscript is very well-written, clear and easy to follow.

The authors first examined which AtCDA proteins encoded by Arabidopsis thaliana have an effect on the CaMV mutational spectrum by performing an AtCDA overexpression in Nicotiana bigelovii. While results are consistent with the expected AtCDA mutagenic activity, I would suggest to them to describe the reasoning behind performing it in $N$. bigelovii plants in order to clarify whether there would be any potential host AtCDAs background-noise effect that could affect or not the transient genes activity results. It may not matter, but I have not found the answers to this question within the text. If that is so, I am guessing that results from the mutant analysis spectra could even improve by providing strong results from the AtCDA1 analysis or even some differences to the other AtCDA genes could be found, as consequence of buffering those effects from negative control samples.

Secondly, they sought to evaluate the effect of suppressing AtCDAs in transgenic A. thaliana plants on the accumulation and mutant spectrum of CaMV. Here, I am a bit concerned whether the general claim that the authors are making with this study is properly warranted. Considering that 
all results of this section are only based on the AtCDA1, this seems to overstate the final conclusion and perhaps this can be slightly tempered. I would recommend either to moderate this conclusion (and title) to only the atCDA1 results or to show evidence of the CaMV load reduction when suppressing the expression of the other AtCDAs. This should then be accompanied by the full description of primers and expression patterns of AtCDA2-8 mRNA analysis in the methods section, in addition to inclusion of statistics data of the mutant spectrum in the results section. This could also increase the appeal of the manuscript.

In this sense, thinking about the general-nature of the findings, it would be very interesting and nice to read any thoughts/perspectives (in the discussion section) about this cytidine deaminase mutagenic activity in some other plant viruses (i.e. RNA virus), which could be infecting through different replicating strategies.

Specific minor comments:

- Please, double check this \% ... 471.43\% increase in G to A transitions

- Colouring treatments of the Fig 3 is a bit confusing. Please keep that as previous figures.

- Table S1: Please, describe that G to A substitutions detected here are shaded in the table.

Is the work clearly and accurately presented and does it cite the current literature? Yes

Is the study design appropriate and is the work technically sound?

Yes

Are sufficient details of methods and analysis provided to allow replication by others? Yes

If applicable, is the statistical analysis and its interpretation appropriate? Yes

Are all the source data underlying the results available to ensure full reproducibility? Yes

Are the conclusions drawn adequately supported by the results? Partly

Competing Interests: No competing interests were disclosed.

Reviewer Expertise: Viral Evolutionary Ecology

I confirm that I have read this submission and believe that I have an appropriate level of expertise to confirm that it is of an acceptable scientific standard.

Author Response ( ) 09 Jun 2017

Santiago F Elena, Evolutionary Systems Virology Group, Instituto de Biología Integrativa de Sistemas (CSIC-UV), Spain 
Dear Dr. Gómez,

Thank you very much for your time in reviewing the manuscript and also for your very constructive comments. Below we provide detailed responses to each one of them.

1. We justify the choice of $N$. bigelovii for our agroinfiltration experiments. Basically, it was a practical choice: the clone of CaMV used in this study does not infect $N$. tabacum nor $N$. benthamiana efficiently and we needed a plant with large enough leaves to be agroinfiltrated.

2. It is true that our results only provide suggestion that AtCDA1 may be involved in C deamination of CaMV genome. We have edited the text to avoid making any unsubstantiated claim. We have also added a paragraph in the Discussion putting our results in the context of recent findings that suggest that only AtCDA 1 may be relevant for the homeostasis of pyrimidines while the other eight members of the gene family may be pseudogenes.

3. We did not quantified the expression levels of AtCDAs 2 - 9, since we decided to focus our attention in AtCDA1 after observing that the expected bias in mutation spectrum was only found in this case.

4. We have added a new paragraph to the Discussion on the potential antiviral role of plant CDAs for other viruses. Unfortunately, possible evidences are only limited to one Potyvirus.

5. The three specific minor comments have been considered: the percentage was correct, coloring in Fig. 3 is right and the legend of Supplementary Tables S1 and S2 have been modified to indicate that $\mathrm{G}$ to $\mathrm{A}$ transitions are shaded in grey.

Competing Interests: No competing interests were disclosed.

The benefits of publishing with F1000Research:

- Your article is published within days, with no editorial bias

- You can publish traditional articles, null/negative results, case reports, data notes and more

- The peer review process is transparent and collaborative

- Your article is indexed in PubMed after passing peer review

- Dedicated customer support at every stage

For pre-submission enquiries, contact research@f1000.com

F1000Research 